\title{
Women Director, Financial Performance and Firm Value: Evidence Mining Sector Companies Listed in Indonesian Stock Exchange
}

\author{
Yani Zulvina $^{1^{*}} \quad$ Makhdalena $^{2} \quad$ Desi Zulvina $^{2} \quad$ Fitri Zulvina $^{2}$ \\ 1.Faculty of Economics and Business, Riau University, 28124, Pekanbaru, Indonesia \\ 2.Faculty of Teacher Training and Education, Riau University, 28124, Pekanbaru, Indonesia \\ 3.Faculty of Economics and Business, Sebelas Maret University, 57126, Solo, Indonesia \\ 4.Directorate General of Taxes, 13140, Jakarta, Indonesia
}

\begin{abstract}
Study of female directors, financial performance and firm value has been widely carried out by previous researchers, but the results have not been consistent, namely several have a positive effect and some have a negative effect. Thus, we are interested in re-examining this topic. We aim to examine and analyze the effect of female directors and financial performance on firm value. And the control variables in this study are firm size, leverage and age. The population of this study are mining sector companies that are listed on the Indonesia Stock Exchange and have complete data on the variables studied for the 2017-2019 period totaling 31 companies with 93 years of observation and all researched (census). The study is secondary data, for women director data derived from annual reports obtained through idx.co.id. Meanwhile, financial data such as ROA, Tobin'Q, firm size, leverage and age were obtained from Thomson \& Reuters. The data analysis technique in this study is path analysis used Stata 14. The results showed that female directors had a positive effect on firm value, while financial performance had a negative effect on firm value.
\end{abstract}

Keywords: Agency Problem, Female Directors, Financial Performance

DOI: $10.7176 /$ RJFA/12-16-07

Publication date:August $31^{\text {st }} 2021$

\section{Introduction}

According to Modern Corporation Theory (Berle and Means, 1932), companies must separate the owners (shareholders) and managers (management). This means that the company must separate the functions between management and shareholders. The separation of functions between owners and management means that there is a specialization of functions. With the specialization of functions, the company must make a separation between management activities and control activities. This is done so that there is no overlap between management and control activities. With the separation of functions, it is expected that each function can be responsible for its duties and obligations. Thus, it is expected that the company can operate more effectively and efficiently which in the end the company can achieve its goals optimally.

With the separation of functions between management activities and supervisory activities (shareholders), it means that here there is an agency relationship. Agency relationship is a relationship that arises because of a contract established between the owner (principal) and management (agent) to perform services that are in the interest of the principal (Jensen and Meckling, 1976). Agency relationship (agency relationship) will lead to potential conflicts. The potential for conflict arises due to the human nature of the agent and principal, namely self-interest

Ideally managers should act in the interests of the owners because managers are appointed by the owners, but in reality many managers have goals that conflict with those of the owners. According to Belkaoui (2004) managers are rational and they seek to maximize utility directly with compensation in order to increase their prosperity. Jensen and Meckling (1976) consider that there is a possibility that managers will make decisions to improve their welfare at the expense of shareholders because the agent has more information (asymmetry information) than the principal. According to Jensen and Meckling (1976) agency problems arising from conflicts of interest are common in cooperative activities. According to Jensen and Meckling (1976) the misalignment of goals between the agent and the principal in the agency relationship will cause agency costs for the owner, namely: (1) monitoring costs; (2) bonding costs and (3) residual costs. The emergence of agent costs will affect the company's performance (corporate performance) and will ultimately affect the value of the company (firm value).

Firm value is influenced by many factors, including financial performance (Winarto, 2015; Karima, 2016) and women directors (Martínez, MDCV, \& Rambaud, SC, 2019; Garanina, T., \& Muravyev, A., 2020; Conyon, MJ, \& He, L., 2017). The results of their research have different directions, some are inconsistent, some have a negative effect and some have a positive effect. Thus, the authors are interested in re-examining the influence of women directors and financial performance on firm value for mining sector companies listed on the Indonesia 


\section{Stock Exchange.}

Based on the description above, the formulation of the problem in this study is: Do women directors and financial performance affect firm value in mining sector companies listed on the Indonesia Stock Exchange.

The purpose of this study is to determine and analyze the influence of women directors and financial performance on firm value in mining sector companies listed on the Indonesia Stock Exchange.

The results of this study are expected to be useful for: (1) investors in using their voice to supervise managers in managing the company so that the company's performance increases and ultimately also increases the value of the company; (2) regulators in making policies regarding the composition of the board of directors are viewed from the gender side of companies listed on the Indonesia Stock Exchange.

\section{Literature Review}

\subsection{Modern Corporation Theory}

Modern Corporation Theory (Berle and Means, 1932) states that the company is a system, namely a collection of people (stakeholders), namely: owners, managers (management), suppliers, government and consumers who are interconnected to achieve a goal. The company will not exist if the stakeholders are not complete, because each has a different function.

Berle and Means (1932) stated that the company must be able to increase the prosperity of stakeholders so that the company still exists. In order for the company to exist, the company must work efficiently. According to Adam Smith (1776) in order for companies to work efficiently, companies must specialize, namely the separation between owners and managers. The separation between the owner and the manager means that there is a separation of the functions of management activities and control activities. This is so that each function can account for its duties and obligations and there is no overlap between the activities of managers and controls. Thus, it is expected that the company can operate effectively and efficiently which can ultimately increase the company's objectives optimally and increase the firm value.

\subsection{Agency Theory}

Modern Corporation Theory (Berle and Means, 1932) requires companies to separate the functions between management activities and control activities. This separation of functions is intended so that there is no overlapping of duties and obligations and ultimately can increase the company's objectives optimally.

With the separation of functions between owners (shareholders/principals) and managers (managers/agents), it means that there is an agency relationship, namely a relationship that arises as a result of a contract between the principal and the agent. In order for the agency relationship to run smoothly, the principal must delegate his authority to the agent regulated in a contract (Jensen and Meckling, 1976).

The separation of activity functions between the principal and the agent has the potential to create a conflict of interest. Ideally, the agent appointed by the principal must act in the interests of the principal, but in reality, the agent often has a goal that is contrary to the principal's goal. According to Jensen and Meckling (1976) Conflict of interest between the principal and the agent is common in all collaborations. Conflict of interest arises due to the human nature of the agent and principal, namely self-interest. The agent and the principal are utility maximizers, so there is reason to believe that the agent does not always act in the interests of the principal. Agent actions that conflict with the interests of the principal can be carried out by the agent because the agent has more information (asymmetry information) than the principal (Jensen and Meckling, 1976). According to Belkaoui (2004) agents are rational and always try to maximize utility with compensation to increase their prosperity. Thus, agency problems that arise due to self-interest between agents and principals ultimately affect financial performance and will have an impact on firm value.

\subsection{Firm Value}

Firm value is an investor's perception of a company which is often associated with stock prices in the market. Research on firm value has been carried out by many researchers, including Gago et al (2016) examining the relationship of corporate social responsibility (CSR), board composition and firm performance (Tobin's Q). Gago et al (2016) used a sample of companies listed in Germany that were included in IBEX 35 for the period 2005-2010. The results of Gago et al's research (2016) show that the percentage of independent directors has an effect on the company's CSR activities and CSR acts as a mediating relationship between independent directors and firm value.

Research conducted by Winarto (2015) on companies listed on the Indonesia Stock Exchange for the period 2005-2010 using regression results that Financial Performance (ROI) has a positive effect on Firm Value and this research is contrary to research conducted by Karima (2016) on property and real estate companies listed on the Indonesia Stock Exchange for the period 2011-2013 using Partial Least Square (PLS) results that Financial Performance (ROE) has a negative and significant relationship with Firm Value, as well as research conducted by Fallatah and Dickins (2012 ) on companies listed in Saudi Arabia using regression results that firm 
performance as measured by return on assets is not related to firm value as measured by Tobin's Q.

Duc and Thi (2013) conducted a study on companies listed on the Ho Chi Minh Stock Exchange and Hanoi Stock Exchange for the period 2007-2012 with 2775 years of observation. Duc and Thi (2013) tested the influence of corporate ownership (state ownership and foreign ownership). ) to firm performance as measured using Tobin's Q (share's market price x number of outstanding share book value of debt) and ROA. The control variables in this study are firm size (log of total assets), profitability (operating earnings over total assets), firm age, leverage (total debt over total assets), investment (capital expenditure divided by total sales), capital intensity (tangible assets over total assets), liquidity (cash and cash equivalent over total assets). For data analysis Duc and Thi (2013) used regression. The results show that state ownership and foreign ownership are positively related to Tobin's Q. Firm size is positively related to Tobin's Q. Profitability is positively related to Tobin's Q. Firm age is negatively related to Tobin's Q, as well as leverage is negatively related to Tobin's Q. Investment is related to positive with Tobin's Q. Capital Intensity is negatively related to Tobin's Q. Liquidity is positively related to Tobin's Q.

Lau and Tong (2008) tested the effect of government ownership on firm value (Tobin's Q). Data were obtained from 15 GLCs listed on the Malaysian Stock Market for the period 2000-2005. Lau and Tong (2008) used regression to analyze the data. Lau and Tong (2008) found research results that government ownership had a positive and significant effect on firm value and none of the control variables had a significant effect on firm value. Foreign ownership has a negative effect on firm value but not significant. Size has a positive effect on firm value but not significant. Leverage has a negative effect on firm value but not significant. Profitability has a positive effect on firm value but not significant.

Martínez, MDCV, \& Rambaud, SC (2019, Spanish Stock Exchange IBEX35 for a fifteen-year period: 2003-2017. The results show that women directors have a positive effect on Tobin's Q. Furthermore, Garanina, T., \& Muravyev, A. ( 2020) conducted a study in Russia. The results showed that women directors had a positive influence on Tobin'Q, ROE and ROA. Likewise with research conducted by Agyemang-Mintah, P., \& Schadewitz, H. (2019). Agyemang -Mintah, P., \& Schadewitz, H. (2019) conducted a study on companies in the United Kingdom and found that board diversity (measured by the percentage of women) has a positive impact on firm value. Ararat, M., \& Yurtoglu, BB ( 2020) conducted a study in Turkey and found results that women directors have a positive relationship with firm value (Tobin'Q).And Conyon, MJ, \& He, L. (2017) conducted research in the US by using regression to process data. ta. The results of his research show that women on the board has a positive effect on firm performance (Tobin's Q and ROA).

The results of previous studies show that firm value is influenced by many factors, including women directors and financial performance (Martínez, MDCV, \& Rambaud, S. C, 2019; Garanina, T., \& Muravyev, A, 2020; Agyemang-Mintah, P., \& Schadewitz, H, 2019; Ararat, M., \& Yurtoglu, B. B, 2020; Conyon, MJ, \& He, L, 2017; Fallatah and Dickins, 2012; Winarto, 2015 and Karima, 2016). However, the results of their research differed inconsistently, some were positively related and some were negatively related and some were unrelated. Thus, researchers are interested in re-examining these variables.

Firm value in this study was measured using Tobin's Q (Fallatah and Dickins, 2012; Karima, 2016; Gago et al, 2016; Mian and Nagata, 2015; Winarto, 2015; Chowdhury and Chowdhury, 2010; Lau and Tong, 2008; Wei et al, 2005; Duc and Thi, 2013; Wang and Xiao 2009; Lihui and Saul, 2008; Nazli Anum Mohd Ghazali, 2010; Sami et al, 2011; Mei Yu, 2013; Mak and Kusnadi, 2005).

\subsection{Financial Performance}

Financial Performance is the ability of company management to generate profits in managing company resources entrusted to it. Research on financial performance has been widely carried out by previous researchers, such as the research conducted by Winarto (2015) on companies listed on the Indonesia Stock Exchange for the period 2005-2010 using regression resulting that Financial Performance (ROI) has a positive effect on Firm Value and research This is in contrast to research conducted by Karima (2016) on property and real estate companies listed on the Indonesia Stock Exchange for the period 2011-2013 using Partial Least Square (PLS) to process data. The results of Karima's research (2016) show that Financial Performance (ROE) has a negative and significant relationship with Firm Value, as well as research conducted by Fallatah and Dickins (2012) on companies listed in Saudi Arabia using regression. on assets is not related to firm value as measured by Tobin's Q.

Duc and Thi (2013) conducted a study on companies listed on the Ho Chi Minh Stock Exchange and Hanoi Stock Exchange for the period 2007-2012 with 2775 years of observation. Duc and Thi (2013) tested the influence of corporate ownership (state ownership and foreign ownership). ) on firm performance as measured using Tobin's Q (share's market price x number of outstanding shares + book value of debt) and ROA. And the control variables are firm size (log of total assets), profitability (operating earnings over total assets), firm age, leverage (total debt over total assets), investment (capital expenditure divided by total sales), capital intensity (tangible assets). over total assets), liquidity (cash and cash equivalent over total assets). For data analysis Duc and Thi (2013) used regression. The results show that state ownership and foreign ownership are positively 
related to Tobin's Q. Firm size is positively related to Tobin's Q. Profitability is positively related to Tobin's Q. Firm age is negatively related to Tobin's Q, as well as leverage is negatively related to Tobin's Q. Investment is related to positive with Tobin's Q. Capital Intensity is negatively related to Tobin's Q. Liquidity is positively related to Tobin's Q.

Lau and Tong (2008) tested the effect of government ownership on firm value (Tobin's Q). Data were obtained from 15 GLCs listed on the Malaysian Stock Market for the period 2000-2005. By using regression to analyze the data, Liu and Tong (2008) found that government ownership had a positive and significant relationship with firm value and none of the control variables had a significant effect on firm value. Foreign ownership has a negative effect on firm value but not significant. Size has a positive effect on firm value but not significant. Leverage has a negative effect on firm value but not significant. Profitability has a positive effect on firm value but not significant.

Bashir et al (2003) examined the relationship between ownership structure and performance with a sample of 100 companies listed on the Karachi stock exchange (50 private and 50 public) for the period 2007-2-11. Performance is measured by ROA, profitability, leverage, assets turnover, earnings per share and Tobin's Q, all of these are independent variables. And as the dependent variable used equity. The statistics used for data analysis are mean, OLS, correlation and T-test. The results show that the performance of privately owned firms is better than the performance of publicly owned firms. All independent variables except Tobin's Q are significantly related to the dependent variable (equity) where the ultimate contributes to increasing firm performance.

Martínez, M. D. C. V., \& Rambaud, S. C. (2019) Spanish Stock Exchange IBEX35 for a fifteen-year period: 2003-2017. The results of the research by Martínez, MDCV, \& Rambaud, SC (2019) showed that women directors had a positive effect on Tobin's Q. Garanina, T., \& Muravyev, A. (2020) conducted a study in Russia and found that women directors had a positive influence on Tobin. 'Q, ROE and ROA.

Agyemang-Mintah, P., \& Schadewitz, H. (2019) conducted a study on companies in the United Kingdom and found that board diversity (measured by the percentage of women) had a positive impact on firm value. The same results were also found by Ararat, M., \& Yurtoglu, B. B. (2020). Ararat, M., \& Yurtoglu, B. B. (2020) conducted a study in Turkey found that women directors had a positive relationship with firm value (Tobin'Q). And so is the research conducted by Conyon, M. J., \& He, L. (2017). Conyon, M. J., \& He, L. (2017) conducted research in the US by using regression to process data. The results showed that women on the board had a positive effect on firm performance (Tobin's Q and ROA).

\subsection{Women Director}

Women directors are women who are on the board of directors. Research on female directors has been widely carried out by previous researchers, such as: Steare and Stamboulides (2008) measuring a person's moral DNA from the system they enter the workplace and he found that women have higher morale than men's morale as measured by the value of honesty, politeness, attention and the reason someone does a job. Peterson et al. (1991) have also examined female directors, the results show that women are more concerned with ethical issues and value ethical issues more highly than men. And so are the results of research conducted by Eynon et al. (1997) which shows the results that women have a higher moral reasoning value than men. Furthermore, Sweeney et al. (2010) support the research conducted by Peterson et al. (1991) and Eynon et al. (1997) who found that women have higher ethical judgments than men.

Research conducted by Lückerath (2013) on the financial performance of Dutch companies with and without women on the board of directors of 99 companies listed on the Dutch Women's Board Index. The results show that companies with women directors perform better than companies without women on their boards. In contrast to the results of research conducted by Singhathep and Pholphirul (2015) on manufacturing sector companies in Thailand, it was stated that female CEOs of manufacturing companies in Thailand turned out to have a negative effect on the company's financial performance. While the results of research conducted by Qian (2016) concluded that company performance is positively related to female directors. Likewise, the results of research conducted by Post and Byron (2014) concluded that women in directors are positively related to the company's financial performance. The same thing was also produced by Brahma et al (2020) who conducted research in the UK. The results of his research conclude that there is a positive and significant relationship between gender diversity and the company's financial performance. The results of this study were more significant when 3 or more women became directors compared to 2 women or less. While the results of research conducted by Mohammad et al. (2018) found that there was no significant correlation between the percentage of women on the board of directors, top and medium level executive management with financial performance.

Salloum et al. (2016) conducted a study of the top 30 Lebanese companies to see the effect of the presence of women in management on company performance. The results show that the presence of women in management in Lebanon is not positively correlated with the company's financial performance. Women in high managerial positions are most likely members of the family that owns the business, and therefore they are not 
directly concerned with business management. In addition, a large number of women surveyed in the sample were married. As a result, their priorities change, and they put their family before their career development.

Emestine \& Setyaningrum (2019) examines the relationship between the characteristics of the Chief Executive Officer (CEO) and company performance. by using Tobin's Q to measure company performance; while CEO characteristics are measured by tenure, age, professional certification in finance or accounting, further education in finance or accounting, status (insider or outsider) and gender. The hypothesis was tested using regression analysis using 235 firm-year observations from six ASEAN countries (Singapore, Malaysia, Indonesia, Thailand, the Philippines, and Vietnam) in 2015. The results showed that the age and tenure of the CEO had a positive relationship with the company. performance. This study is important because it provides evidence on the relationship between CEO characteristics and firm performance. The characteristics of the CEO will have a positive impact on company performance. Overall, investors need to pay attention to the essence of a CEO who is proven to be able to influence better company performance in making investment decisions.

Bianchi \& Iatridis (2014) examined the impact of board gender diversity on corporate financial performance. The focus is on the CAC 40 constituents and the investigative period from 2008 to 2012 . The study finds that firms with a higher proportion of women on their boards outperform firms with a lower proportion in terms of return on sales and EBITDA margins. The questionnaire survey shows that increasing board gender diversity leads to better corporate governance and increased firm value.

Martínez, M. D. C. V., \& Rambaud, S. C. (2019) researching the Spanish Stock Exchange IBEX35 for a fifteen-year period: 2003-2017. The results of his research show that women directors have a positive effect on Tobin's Q. Furthermore, Garanina, T., \& Muravyev, A. (2020) conducted research in Russia. The results of research conducted by Garanina and Muravyev show that women directors have a positive influence on Tobin'Q, ROE and ROA. The results of the same study were also found by Agyemang-Mintah, P., \& Schadewitz, H. (2019). Agyemang-Mintah, P., \& Schadewitz, H. (2019) conducted a study on companies in the United Kingdom and found that board diversity (measured by the percentage of women) had a positive impact on firm value.

Ararat, M., \& Yurtoglu, B. B. (2020) conducted a study in Turkey. Ararat, M., \& Yurtoglu, B. B. (2020) found that women directors had a positive relationship with firm value (Tobin's Q). Furthermore, Conyon, M. J., \& He, L. (2017) conducted research in the US by using regression to process data. The results of Conyon, M. J., $\&$ He, L. (2017) show that women on the board have a positive effect on firm performance (Tobin's Q and ROA).

\subsection{Financial Performance and Firm Value}

Financial Performance is the ability of company management to generate profits in managing company resources entrusted to it. Firm value is an investor's perception of a company which is often associated with stock prices in the market.

Research on financial performance and firm value has been carried out by Winarto (2015) on companies listed on the Indonesia Stock Exchange for the period 2005-2010. Winarto (2015) uses regression to analyze the data. The results of Winarto's (2015) research show that Financial Performance (ROI) has a positive effect on Firm Value. Furthermore, Duc and Thai (2013) conducted a study using data from the Ho Chi Minh Stock Exchange and the Hanoi Stock Exchange for the period 2007-2012 with 2775 years of observation. For data analysis Duc and Thi (2013) used regression. The results of research by Duc and Thi (2013) show that financial performance (profitability) is positively related to Tobin's Q.

Lau and Tong (2008) examined the effect of financial performance (profitability) on firm value (Tobin's Q). Data were obtained from 15 GLCs listed on the Malaysian Stock Market for the period 2000-2005. By using regression to analyze the data, Liu and Tong (2008) found that profitability has a positive effect on firm value but not significant.

\subsection{Women Director and Firm Value}

Women director is the presence of women on the board of directors as measured by the percentage of women on the board of directors. Firm value is an investor's perception of a company which is often associated with the market share price as measured by Tobin's Q.

Research on women directors and firm value has been conducted by Bianchi \& Iatridis (2014). Bianchi \& Iatridis (2014) examined the impact of board gender diversity on financial performance. The focus is on the CAC 40 constituents and the investigative period from 2008 to 2012. The study finds that firms with a higher proportion of women on their boards outperform firms with a lower proportion in terms of return on sales and EBITDA margins. The questionnaire survey shows that increasing board gender diversity leads to better corporate governance and increased firm value. Furthermore, Martínez, M. D. C. V., \& Rambaud, S. C. (2019) conducted research on the Spanish Stock Exchange IBEX35 for a fifteen-year period 2003-2017. The results of his research show that women directors have a positive effect on Tobin's Q. Garanina, T., \& Muravyev, A. (2020) have also conducted research in Russia. The results showed that women directors had a positive influence on Tobin'Q, ROE and ROA. The same results were also found by Agyemang-Mintah, P., \& Schadewitz, H. (2019) 
who conducted research on companies in the United Kingdom. Agyemang-Mintah, P., \& Schadewitz, H. (2019) found that board diversity (measured by the percentage of women) has a positive impact on firm value. And so is the research conducted by Ararat, M., \& Yurtoglu, B. B. (2020). Ararat, M., \& Yurtoglu, B. B. (2020) conducted a study in Turkey found that women directors had a positive relationship with firm value (Tobin'Q).

Conyon, M. J., \& He, L. (2017) conducted research in the US by using regression to process data. The results of his research show that women on the board has a positive effect on firm performance (Tobin's Q and ROA). Likewise with the research conducted by Issaa et al (2019). Issaa et al (2019) conducted research on companies listed in Kuwait for the period 2012 to 2014. The results showed that board gender diversity was positively related to firm value.

\section{Research Methods}

The type of this research is descriptive quantitative research. The objects of this study are women directors with indicators of the proportion of women directors on directors, financial performance with indicators of ROA and firm value with indicators of Tobin's Q. While the control variables in this study are firm size, leverage and age. The population of this study are mining sector companies that are listed on the IDX and have complete data for the 2017-2019 period totaling 31 companies with 93 years of observation, all studied (census). The type of data from this research is secondary data, for female directors data comes from the annual report obtained through idx.co.id. As for ROA, Tobin'Q, firm size, leverage and age data obtained from Thomson \& Reuters. The data analysis technique in this study uses path analysis with the help of Stata 14.

Table 1. Operationalization of Research Variables

\begin{tabular}{|c|c|c|c|}
\hline Variable & Concept & Indicator & Scale \\
\hline Women Directors $\left(\mathrm{X}_{1}\right)$ & $\begin{array}{l}\text { Women who become company } \\
\text { directors }\end{array}$ & Proportion of female directors & Ratio \\
\hline $\begin{array}{l}\text { Financial Performance } \\
\left(\mathrm{X}_{2}\right)\end{array}$ & $\begin{array}{l}\text { Financial performance is the } \\
\text { result of management's ability to } \\
\text { manage the company's resources }\end{array}$ & Return on Assets (ROA) & Ratio \\
\hline Leverage $\left(\mathrm{X}_{3}\right)$ & $\begin{array}{l}\text { Leverage, which is the number of } \\
\text { assets financed with debt }\end{array}$ & the ratio of debt to assets & Ratio \\
\hline Age $\left(\mathrm{X}_{4}\right)$ & $\begin{array}{l}\text { Company age since listed (Liu \& } \\
\text { Anbumozhi, 2009) }\end{array}$ & Since listing until now & Ratio \\
\hline Firm size & $\begin{array}{l}\text { Firm size is the size of the } \\
\text { company }\end{array}$ & $\begin{array}{l}\text { Natural logarithm of total assets } \\
\text { Tobin's Q (share's market price }\end{array}$ & Ratio \\
\hline Firm Value & $\begin{array}{l}\text { Firm value is an investor's } \\
\text { perception of a company which is } \\
\text { often associated with stock prices } \\
\text { in the market. }\end{array}$ & $\begin{array}{l}\text { x number of outstanding share }+ \\
\text { book value of debt)/ book value } \\
\text { of total assets) }\end{array}$ & Ratio \\
\hline
\end{tabular}

\section{Result and Discussion}

\subsection{Results of Descriptive Test of Firm Value Variables}

Firm value is an investor's perception of the company as measured by the company's stock price in the market. In this study, firm value was measured using Tobin's Q (share's market price $\mathrm{x}$ number of outstanding shares + book value of debt) / book value of total assets). Mining sector companies listed on the Indonesia Stock Exchange have an average firm value of 1,4152. And companies that have firm values below the average are as many as 68 companies $(73.12 \%)$ while those above the average are as many as 25 companies $(26.88 \%)$. This means that most of the mining sector companies listed on the Indonesia Stock Exchange have a poor market value.

Tabel 2. Descriptive Analysis Company Firm Value (Tobin's Q)

\begin{tabular}{|l|r|r|}
\hline \multicolumn{1}{|c|}{ Firm Value } & \multicolumn{1}{|r|}{ Total } & Percentage \\
\hline Standard Deviation & 1.1035 & - \\
Mean & 1.4152 & 73.12 \\
Below average & 68 & 26.88 \\
Above average & 25 & - \\
Maximum & 7.4107 & - \\
Minimum & 0.1824 & \\
\hline
\end{tabular}

Source: Secondary data processing (2021)

4.2 Results of Descriptive Analysis of Financial Performance Variable

Financial performance is the result of management's ability to manage the company's resources which is 
calculated by return on assets (ROA). The data in Table 3 shows that the average financial performance of mining sector companies listed on the IDX is .0514 or 5.14\%. The average ROA is below the industry standard, which is $30 \%$ (Kasmir, 2016).

Table 3. Descriptive Analysis Financial Performance (ROA)

\begin{tabular}{|l|r|r|}
\hline \multicolumn{1}{|c|}{ Financial Performance } & \multicolumn{1}{|c|}{ Total } & Percentage \\
\hline Standard Deviation & 0.2215 & - \\
Mean & 0.0696 & 58 \\
Below average & 54 & 42 \\
Above average & 39 & - \\
Maximum & .6054 & - \\
Minimum & -1.5383 & \\
\hline
\end{tabular}

Source: Secondary data processing (2021)

\subsection{Results of Descriptive Analysis of Women Director Variable}

Women directors are women who occupy the board of directors in a company with an indicator that is the number of women on the board of directors compared to the total directors. The data in Table 4 shows that the average female directors in mining sector companies listed on the IDX is 0.1447 or $14.47 \%$. On average, female directors from mining sector companies listed on the IDX have female directors below the standard set by Alexander, which is $33 \%$.

Table 4. Descriptive Analysis Women Director

\begin{tabular}{|l|r|r|}
\hline \multicolumn{1}{|c|}{ Financial Performance } & \multicolumn{1}{|c|}{ Total } & Percentage \\
\hline Standard Deviation & 0.0812 & - \\
Average & 0.0689 & 52.67 \\
Below average & 49 & 47.31 \\
Above average & 44 & - \\
Maximum & 0.2857 & - \\
Minimum & 0 & \\
\hline
\end{tabular}

\subsection{Hypothesis Test Results}

Diagrammatically the form of the variable structure of women directors, financial performance, age, leverage and size on the firm value of the mining sector listed on the IDX is shown in Figure 2. Furthermore, the influence of female directors, financial performance, age, leverage and firm size variables on the mining sector firm value which are listed on the IDX either simultaneously or partially as shown in Table 4.

The magnitude of the influence of women directors, financial performance, age, leverage and size on firm value simultaneously can be seen from the value of the coefficient of determination (R), which is 0.135 or $13.5 \%$ while the remaining $0.865(1-0.135)$ is influenced by other factors outside the factors studied. . The low simultaneous influence of female directors, financial performance, age, leverage and size variables on firm value, which is $13.5 \%$ indicates that there are many other factors that affect firm value. These other factors are management ownership, institutional ownership, managerial labor, independent commissioners and audit committees (Agrawal and Knoeber, 1996) and blockholders (Makhdalena, 2014).

Table 4. The Influence of Female Directors (X1), Financial Performance (X2), Age (X3), Leverage (X4) and Size (X5) on Firm Value (Y) in Mining Sector Companies listed on BEI

\begin{tabular}{|l|c|c|}
\hline \multicolumn{1}{|c|}{ Variable } & Path Coefficient (Beta) & Impact \\
\hline Women directors $\left(\mathrm{X}_{1}\right)$ & 0.687 & 0.001 \\
Financial Performance $(\mathrm{X} 2)$ & -0.145 & 0.021 \\
Age $\left(\mathrm{X}_{2}\right)$ & -0.026 & 0.000 \\
Leverage $\left(\mathrm{X}_{3}\right)$ & -0.261 & 0.068 \\
Size $\left(\mathrm{X}_{4}\right)$ & -0.044 & 0.002 \\
\hline
\end{tabular}

$\mathrm{R}=0.135$

Source: Secondary data processing (2021) 


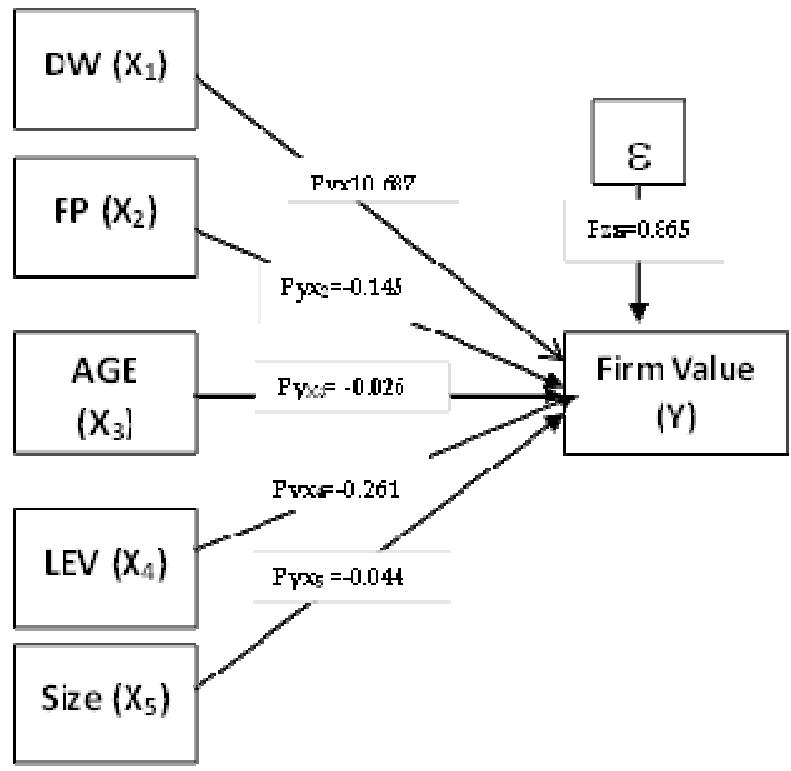

Figure 2. Path Chart of The Influence of Women directors, Firm Performance, Age, Leverage and Size on Firm Value

\subsection{Discussion}

Testing the research hypothesis shows that women directors have a positive effect on firm value in mining sector companies listed on the Indonesia Stock Exchange. The results of this study are in line with research conducted by Bianchi \& Iatridis (2014). Bianchi \& Iatridis (2014) examined the impact of board gender diversity on financial performance. The focus is on the CAC 40 constituents and the investigative period from 2008 to 2012 . The study finds that firms with a higher proportion of women on their boards outperform firms with a lower proportion in terms of return on sales and EBITDA margins. The questionnaire survey shows that increasing board gender diversity leads to better corporate governance and increased firm value.

Martínez, M. D. C. V., \& Rambaud, S. C. (2019 conducted research on the Spanish Stock Exchange IBEX35 for a fifteen-year period: 2003-2017. The results showed that women directors had a positive effect on Tobin's Q.

Garanina, T., \& Muravyev, A. (2020) conducted research in Russia. The results showed that women directors had a positive influence on Tobin'Q, ROE and ROA. The same results were also found by AgyemangMintah, P., \& Schadewitz, H. (2019) who conducted research on companies in the United Kingdom found that board diversity (measured by the percentage of women) had a positive impact on firm value. And so is the research conducted by Ararat, M., \& Yurtoglu, B. B. (2020). Ararat, M., \& Yurtoglu, B. B. (2020) conducted a study in Turkey found that women directors had a positive relationship with firm value (Tobin'Q).

Conyon, M. J., \& He, L. (2017) conducted research in the US by using regression to process data. The results showed that women on the board had a positive effect on firm performance (Tobin's Q and ROA). Likewise with the research conducted by Issaa et al (2019). Issaa et al (2019) conducted research on companies listed in Kuwait for the period 2012 to 2014. The results showed that board gender diversity was positively associated with firm value. This is in line with the results of research conducted by Steare and Stamboulides (2008) measuring a person's moral DNA from the system they enter the workplace and he found that women have higher morale than men's morale which is measured by the values of honesty, politeness, attention and the reason someone does a job. Peterson et al. (1991) have also examined female directors, the results show that women are more concerned with ethical issues and value ethical issues more highly than men. And so are the results of research conducted by Eynon et al. (1997) which shows the results that women have a higher moral reasoning value than men. Sweeney et al. (2010) support the research conducted by Peterson et al. (1991) and Eynon et al. (1997) who found that women have higher ethical judgments than men.

Testing the research hypothesis shows that financial performance has a very small and negative effect on firm value in mining sector companies listed on the Indonesia Stock Exchange, which is 0.021. The results of this study are in line with research conducted by Karima (2016) which shows that Financial Performance has a negative and significant relationship with Firm Value, as well as research conducted by Fallatah and Dickins (2012) on companies listed in Saudi Arabia using regression. performance as measured by return on assets is not related to firm value as measured by Tobin's Q. And the results of this study contradict the theory which states that financial performance has a positive effect on firm value. The results of this study also contradict the research conducted by Duc and Thi (2013) using regression. The results of research by Duc and Thi (2013) show 
that financial performance (profitability) is positively related to Tobin's Q. The results of this study also contradict the research conducted by Lau and Tong (2008) which examined the effect of financial performance (profitability) on firm value ( Tobin's Q). Data were obtained from 15 GLCs listed on the Malaysian Stock Market for the period 2000-2005. By using regression to analyze the data, Liu and Tong (2008) found that profitability has a positive effect on firm value but not significant.

The results of testing the hypothesis of this study indicate that financial performance has a very small and negative effect on firm value, which is 0.021 . This happens because the average ROA is very small, which is $6.96 \%$, far below the industry average, which is $30 \%$ (Kasmir, 2016). And most of the mining sector companies listed on the Indonesia Stock Exchange have an ROA below the average, which is as much as $58 \%$. This also happens to the firm value (Tobin's Q), with an average of 1.4. And most of the mining sector companies listed on the Indonesia Stock Exchange have a Tobin's Q number below the average, which is $73.11 \%$. Thus, the effect of ROA on Tobin;s Q is also very small.

\section{Conclusion, Limitations and Suggestions}

\subsection{Conclusion}

Based on the problem formulation and research hypotheses and analysis of research results, it can be concluded that simultaneously women directors, financial performance, firm size, leverage and age have an effect on firm value, and the partial influence is as follows: (1) women directors have a positive effect on firm value of mining companies listed on the Indonesia Stock Exchange; (2) financial performance has a negative and very small effect on firm value in mining companies listed on the Indonesia Stock Exchange; (3) age does not affect the firm value of mining companies listed on the Indonesia Stock Exchange; (4) leverage has a negative effect on firm value in mining companies listed on the Indonesia Stock Exchange; (5) firm size does not affect the firm value of mining companies listed on the Indonesia Stock Exchange.

\subsection{Limitations}

This study used a population with a small number. This study also used the female director indicator, only the percentage of women on the board of directors.

\subsection{Suggestions}

Based on the conclusion of the research, to increase firm value, some suggestions are given as follows: (1) for the next researcher, it is recommended to use firm value variable, it is recommended to look at other variables that affect firm value other than women director, financial performance, firm size, leverage and age. . (2) for academics, it is hoped that the results of this study can provide valuable input in learning financial accounting, especially on Financial Statement Analysis material. While the operational suggestions that can be given are: (1) for regulators, it is suggested that they can provide policies that can increase firm value such as the policy to determine the composition of women directors in companies listed on the Indonesia Stock Exchange which are larger as determined by Alexander, which is 33\%. For investors, it is hoped that they can use their voice in supervising the company's operations by management to improve company performance and ultimately increase firm value.

\section{References}

Agrawal, A., \& Knoeber, C. R 1996, 'Firm performance and mechanisms to control agency problems between managers and shareholders', Journal of financial and quantitative analysis, 377-397.

Agyemang-Mintah, P., \& Schadewitz, H 2019, 'Gender diversity and firm value: evidence from UK financial institutions', International Journal of Accounting \& Information Management, 27(1), 2-26

Ararat, M., \& Yurtoglu, B. B 2020, 'Female directors, board committees, and firm performance: Time-series evidence from Turkey', Emerging Markets Review, 100768.

Belkaoui, A. 2004, Accounting Theory, Five edition Harcouit \& Brace.

Berle, A. A., \& Means, G. G. C 1991, The modern corporation and private property. Transaction publishers.

Bianchi, M., \& Iatridis, G. 2014, 'Board gender diversity and corporate financial performance: evidence from CAC 40'

Brahma, S., Nwafor, C., \& Boateng, A 2020, 'Board gender diversity and firm performance: The UK evidence', International Journal of Finance \& Economics.

Chowdhury. A, S. Paul Chowdhury 2010, 'Impact of capital structure on firm,s value: Evidence from Bangladesh.', BEH-Busuness and Economic Horizons 3 (3) :111-122.

Conyon, M. J., \& He, L. 2017, 'Firm performance and boardroom gender diversity: A quantile regression approach', Journal of Business Research, 79, 198-211.

Duc N. Phung dan Thi P. T. Hoang 2013, 'Corporate Ownership and Firm Performance in Emerging Market: A studyof Vietnamese Listed Firms', Proceeding of Word Business and Social Science Research Conference 
24-25 October, 2013, Novotel Bangkok on Siam Squre, Bangkok, Thailand, ISBN: 978-1-922069-33-7.

Emestine, I., \& Setyaningrum, D 2019, 'CEO Characteristics and Firm Performance; Empirical Studies from ASEAN Countries’. In 2018 International Conference on Islamic Economics and Business (ICONIES 2018) Atlantis Press.

Eynon, G., Hills, N. T., \& Stevens, K. T 1997, 'Factors that influence the moral reasoning abilities of accountants: Implications for universities and the profession', Journal of Business ethics, 16(12), 1297-1309.

Fallatah Y dan Dickins D 2012, 'Corporate Governance and Firm Performance and Value in Saudi Arabia', African Journal of Business Management 6 (36): 10025-10034.

Gago. R. F, Garcia. L. C dan Nieto. M 2016, 'Corporate social responsibility, board of directors and firm performance: an analysis of their relationships', Review of Managerial Science 10 (1): 85-104

Garanina, T., \& Muravyev, A 2020, 'The gender composition of corporate boards and firm performance: Evidence from Russia', Emerging Markets Review.

Issaa, A., Elfekyb, M. I., \& Ullahc, I 2019, 'The Impact of Board Gender Diversity on Firm Value: Evidence from Kuwait'

Jensen, M and W. Meckling 1976, 'Theory of the Firm: Managerial Behavior, Agency Cost and Ownership Structure', Journal of Finance Economic 3: 305-360.

Karima. T 2016, 'The Influence of Internal Factor on Financial Performance and Firm Value: Evidence from Property and Real Estate Companies Listed in Indonesia Stock Exchange', OIDA International Journal of Sustainable Development 09 (03): 89-107.

Kasmir 2016, Analisis Laporan Keuangan. Jakarta: Raja Grafindo Persada

Lau, Y. W., \& Tong, C. Q 2008, 'Are Malaysian government-linked companies (GLCs) creating value', International Applied Economics and Management Letters, 1(1), 9-12.

Lihui Tian dan Saul Estrin 2008, 'Retained state shareholding in Chinese PLCs: Does government ownership always reduce corporate value?', Journal of Comparative Economics 36: 74-89.

Lückerath-Rovers, M 2013, 'Women on boards and firm performance', Journal of Management \& Governance, 17(2), 491-509.

Mak. Y. T, Kusnadi. Y 2005, 'Size really matter: Further evidence on the negative relationship between board size and firm value', Pasific-Basin Finance Journal. Vol. 13 (3): 301-318.

Makhdalena, M 2014, 'Pengaruh Blockholders Ownership, Firm Size dan Leverage Terhadap Kinerja Keuangan Perusahaan', EKUITAS (Jurnal Ekonomi dan Keuangan), 18(3), 277-292.

Martínez, M. D. C. V., \& Rambaud, S. C 2019, 'Women on corporate boards and firm's financial performance', In Women's Studies International Forum (Vol. 76, p. 102251).

Mei Yu 2013, 'State ownership and firm performance: Empirical evidence from Chinese listed companies. China', Journal of Accounting Research. Vol. 6 (2): 75-87.

Mian. R, K. Nagata 2015, 'Foreign Institutional Ownership and the Valuation Effect of Investment and Payout Decisions', Journal of Finance and Economics. Vol. 3, No. 5, pp: 97-104

Mohammad, S. J., Abdullatif, M., \& Zakzouk, F 2018, 'The effect of gender diversity on the financial performance of Jordanian banks', Academy of Accounting and Financial Studies Journal, 22(2), 1-11.

Nazli Anum Mohd Ghazali 2010, 'Ownership structure, corporate government and corporate performance in Malaysia', International Journal of Commerce and Management 20 (2): 109-119.

Peterson, R. A., Beltramini, R. F., \& Kozmetsky, G.,1991, 'Concerns of college students regarding business ethics: A replication', Journal of Business Ethics, 10(10), 733-738.

Post, C., \& Byron, K 2015, 'Women on boards and firm financial performance: A meta-analysis', Academy of management Journal, 58(5), 1546-1571.

Qian, M. 2016, 'Women's leadership and corporate performance', Asian Development Bank Economics Working Paper Series, (472).

Salloum, C., Azzi, G., Mercier-Suissa, C., \& Khalil, S. 2016, The rise of women and their impact on firms' performance, International Journal of Entrepreneurship and Small Business, 27(2-3), 213-246.

Sami. H, Justin. W, H. Zhou 2011, 'Corporate governance and operating performance of Chinese listed firms', Journal of International Accounting, Auditing and Taxation. 20 (92): 106-114.

Singhathep, T., \& Pholphirul, P. 2015, 'Female CEOs, firm performance, and firm development: evidence from Thai manufacturers', Gender, Technology and Development, 19(3), 320-345.

Steare, R., \& Stamboulides, P. 2008, 'Who's doing the right thing'. London: Roger Steare Consulting Limited

Sweeney, B., Arnold, D., \& Pierce, B. 2010, 'The impact of perceived ethical culture of the firm and demographic variables on auditors', ethical evaluation and intention to act decisions. Journal of Business Ethics, 93(4), 531-551.

Wang. K, X. Xiao 2009, 'Ultimate Government Control Structures and Firm Value: Evidence from Chinese Listed Companies', China Journal of Accounting Research 2 (1): 101-122.

Wei. Z, F. Xie dan S. Zhang 2005, 'Ownership Structure and Firm Value in China's Privatized Firms: 1991- 
2001' Journal of Financial and Quantitative Analysis. 40 (1): 87-108.

Winarto. J 2015, 'The Determinants of Manufacture Firm Value in Indonesia Stock Exchange. International Journal of Information', Business and Management 7 (4) 